\title{
Pathogenesis and Therapy of Primary Cutaneous T-Cell Lymphoma: Collegium Internationale Allergologicum (CIA) Update 2020
}

\author{
Malgorzata Bobrowicz ${ }^{a}$ Christina Fassnacht ${ }^{b, c}$ Desislava Ignatova ${ }^{b, c}$ \\ Yun-Tsan Chang $^{\text {b-e }}$ Florentia Dimitriou $^{b, c}$ Emmanuella Guenova ${ }^{b-e}$ \\ a Department of Immunology, Medical University of Warsaw, Warsaw, Poland; 'b Department of Dermatology,

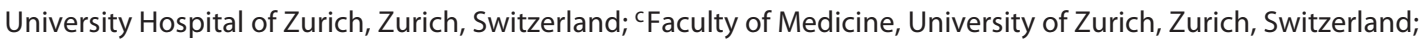

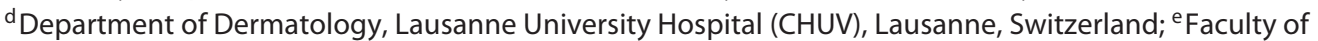 \\ Biology and Medicine, University of Lausanne, Lausanne, Switzerland
}

\section{Keywords}

Skin · T-cell lymphoma · Pathogenesis

\begin{abstract}
Cutaneous T-cell lymphoma (CTCL) is a heterogeneous disease group of unknown etiology with a complex immunological background. As CTCL arises from T cells that have a vital role in the antitumor response, their therapy is largely aimed at reversing the immunological mechanisms leading to or manifesting during this malignancy. Early disease stages can be controlled with skin-directed therapy in most CTCL cases. Still, advanced CTCL has a dismal prognosis and warrants systemic therapy. Despite considerable progress in understanding the pathophysiology of the disease and the numerous systemic treatment options available, longterm remission rates with conventional treatments alone are still low. Allogeneic hematopoietic stem cell transplantation is currently the only curative option for advanced $\mathrm{CTCL}$, including mycosis fungoides and Sézary syndrome.
\end{abstract}

The aims of this review is to summarize the recent findings on the immunology of this heterogeneous disease and to present the advances in its clinical management.

(c) 2020 The Author(s)

Published by S. Karger AG, Basel

\section{Disease Prevalence and Subtypes}

Cutaneous T-cell lymphomas (CTCL) are a heterogeneous group of non-Hodgkin lymphomas arising from the malignant proliferation of skin-homing or skin-resident $\mathrm{T}$ cells $[1,2]$. Although CTCL manifestation in children exists [3], most CTCL typically affect the elderly, with a median age at diagnosis of 55-60 years and an average number of 6.4 new cases per year and per million people [4].

Edited by: H.-U. Simon, Bern.

Malgorzata Bobrowicz and Christina Fassnacht contributed equally to this work.

\begin{tabular}{ll}
\hline karger@karger.com & $\begin{array}{l}\text { (C) } 2020 \text { The Author(s) } \\
\text { Published by S. Karger AG, Basel Oparger } \\
\text { www.karger.com/iaa }\end{array}$ \\
Karger & $\begin{array}{l}\text { This is an Open Access article licensed under the Creative Commons } \\
\text { Attribution-NonCommercial-4.0 International License (CC BY-NC) } \\
\text { (http://www.karger.com/Services/OpenAccessLicense), applicable to } \\
\text { the online version of the article only. Usage and distribution for com- } \\
\text { mercial purposes requires written permission. }\end{array}$
\end{tabular}


The 2 main subtypes of CTCL include the most frequent, i.e., mycosis fungoides (MF), accounting for approximately $60 \%$ of CTCL cases and $50 \%$ of all primary cutaneous lymphomas, and the rare leukemic variant Sézary syndrome (SS), representing around 5\% of CTCL cases. The second most common group, representing approximately $25 \%$ of CTCL, is the group of primary cutaneous CD30+ lymphoproliferative disorders including primary cutaneous anaplastic large lymphoma and lymphomatoid papulosis [5]. Other CTCL subtypes are very rare $[5,6]$.

\section{Clinical Manifestations}

MF and SS originate from distinct CD4+ T-cell populations [7] and vary in terms of their prognosis as well as their clinical manifestations [8], with some overlapping symptoms such as chronic cutaneous lesions, associated with scaly rash, pruritus, burning, and sometimes pain [9] with recurrent infections, thus having a significant impact on the quality of life due to subsequent psychological problems and sleep disorders $[10,11]$. Most patients with MF present a prolonged, indolent clinical course with initial skin involvement and clinical presentation depending on the stage at diagnosis [12]. Of all MF patients, $71.5 \%$ are in an early stage and $28.5 \%$ are in an advanced stage of the disease, and progression to a higher stage of the disease occurs in $9.7-11.6 \%$ of patients [13]. MF restricted to the skin progresses from a persistent patch stage with finely scaling lesions to a plaque and tumor stage, typically in sun-protected areas over years [8]. Extracutaneous disease initially involves regional lymph nodes and is mostly present with extensive skin involvement with tumors or erythroderma.

In CTCL leukemic variants, including SS and a portion of advanced-stage MF, malignant CD4+ T cells accumulate in the peripheral blood and visceral organs, with a subsequently dismal prognosis. SS is defined as an aggressive leukemic CTCL clinically defined by the triad of erythroderma, generalized lymphadenopathy, and the presence of neoplastic T cells in the skin, lymph nodes, and peripheral blood (Sézary cells) [8]. Cutaneous lesions include erythroderma, plantar and palmar keratoderma, onychodystrophy, ectropion, and diffuse alopecia [14].

\section{Etiology}

The etiology of CTCL remains largely unknown. Viruses, such as human $\mathrm{T}$-cell leukemia virus type 1 , have been previously suggested as drivers of the disease [15], but recent studies do not present enough evidence to support the viral hypothesis in the pathogenesis of MF and SS [16]. Antigen-driven T-cell lymphoproliferation or dyscrasia following medication use [17], as well as genetic factors, i.e., HLA class II alleles predisposing to the disease [18], have been reported. Recent attempts to profile the genomic landscape of CTCL have demonstrated its high heterogeneity. Although the pathogenesis of the disease cannot be attributed to a small subset of well-defined somatic mutations, copy number variations, fusion proteins, and somatic mutations in diverse cellular and signaling pathways might contribute to the pathogenesis of the disease [19-22]. Those include alterations in factors functioning in epigenetic regulation, DNA damage response, cell cycle control, programmed cell death, and Tcell receptor (TCR) signaling, as well as nuclear factor (NF)- $\kappa \mathrm{B}$ and Janus kinase (Jak)/signal transducer and activator of transcription (STAT) pathways [19, 20, 23-26]. Next to those intrinsic drivers, also extrinsic drivers, most commonly Staphylococcus aureus (SA) and its toxins, are under debate [27]. However, epidemiological studies could so far not reliably identify environmental exposure as a trigger for the disease [28].

\section{Malignant T-Cell Heterogeneity}

As the name indicates, CTCL is a disease of T cells, although MF and SS appear to have their origin in different T-cell subtypes [7]. Based on flow cytometry analysis of lymph node or skin-homing molecules and differentiation markers, MF has been characterized as a malignancy of skin-resident effector memory $\mathrm{T}\left(\mathrm{T}_{\mathrm{EM}}\right)$ cells (CCR4+ and CLA+), while SS cells present a phenotype of central memory $\mathrm{T}\left(\mathrm{T}_{\mathrm{CM}}\right)$ cells (CCR7+, CD27+, and L-selectin+) [7]. These findings explain some of the differences in the clinical manifestation of the disease. $\mathrm{T}_{\mathrm{EM}}$ cells are skinresident stationary polarized effector cells producing high amounts of inflammatory cytokines [29] that result in a skin-limited presentation in the form of patches, plaques, or tumors that remain stable for years. A progressive disease with the involvement of blood, lymph nodes, and viscera develops only in a small subset of patients [2]. In contrast, $\mathrm{T}_{\mathrm{CM}}$ are highly proliferative and actively recirculate between the blood, lymph nodes, and skin [2].

Differences in the genetic background of T-cell precursors in these CTCL subtypes have been further proven by comparative genomic hybridization and gene expression analyses [22, 30, 31]. However, malignant $T$ cells differ not only between CTCL subtypes but also between 


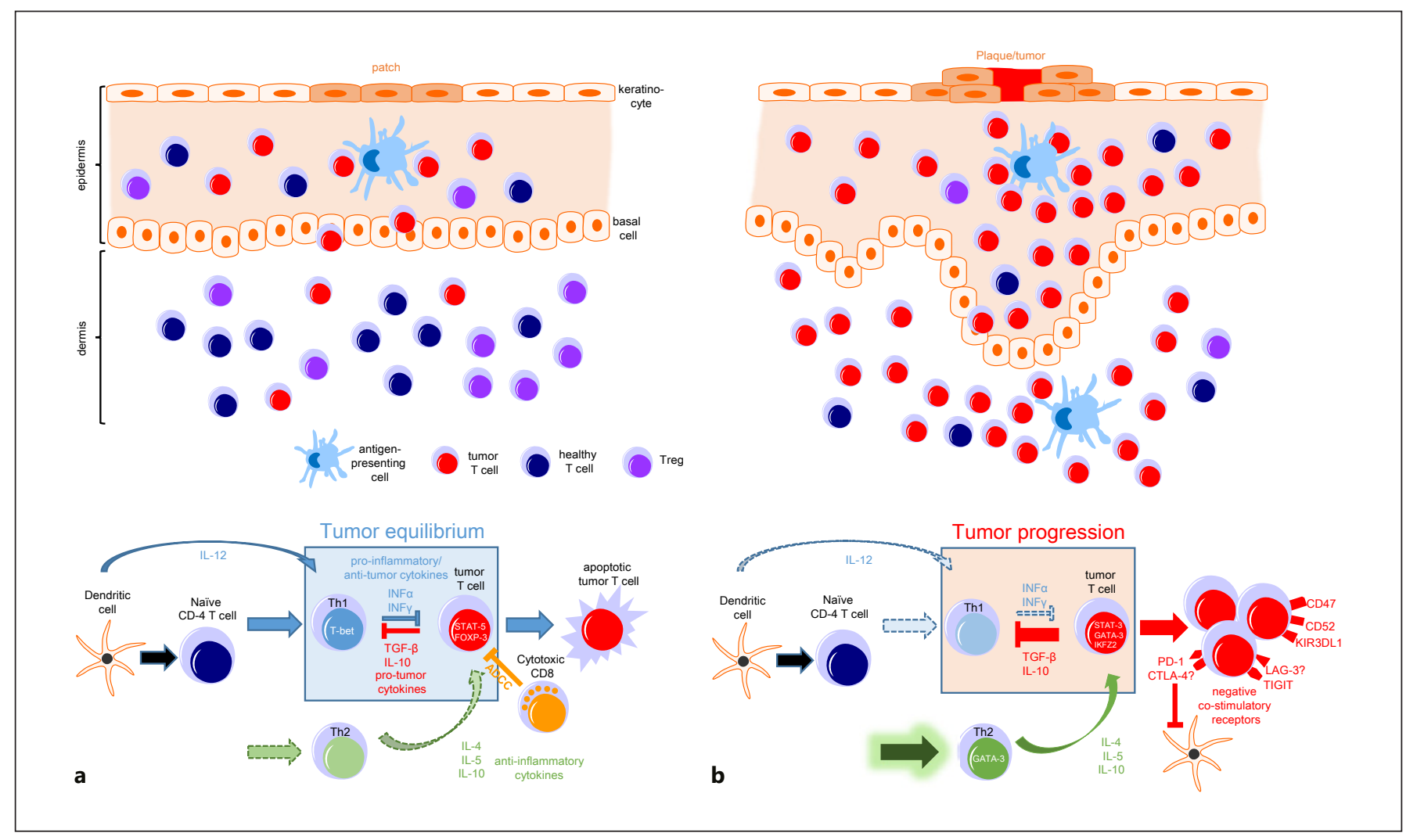

Fig. 1. Immune responses in early- and advanced-stage CTCL. a Early-stage CTCL. Upper panel: schematic illustration of the cellular composition in patch-stage disease. Small populations of tumor $\mathrm{T}$ cells are present mostly in the epidermis and are held in check by surrounding healthy $\mathrm{T}$ cells and regulatory $\mathrm{T}$ cells. Lower panel: immunosurveillance mechanisms are partially intact, the antitumor Th1 immune response can control tumor progression, leading to a tumor equilibrium. b Advanced-stage CTCL. Upper panel: schematic illustration of the cellular composition in plaque/ tumor stage disease. The number of infiltrating tumor $\mathrm{T}$ cells is largely increased and present now also in the dermis, while the number of healthy $\mathrm{T}$ cells and T regulatory cells is decreased. Lower panel: immunosurveillance of the tumor is largely defective. A skewed Th1 immune response and an increased Th2 response, among other mechanisms, lead to immune escape of tumor cells and allow tumor progression. patients with the same disease. In a cohort of SS patients it was observed that not all malignant T-cells were characterized by the $\mathrm{T}_{\mathrm{CM}}$ phenotype, but malignant cells from a subgroup of SS patients (18 out of 47 patients) expressed markers of a naive, more stem cell-like phenotype, such as high levels of CD45RA [32].

Finally, it has become evident that malignant T-cells show a high intrapatient variability, and follow-up data of SS patients suggests also an evolution in the phenotype of SS cells, demonstrating their plasticity [32]. Single-cell RNA sequencing combined with flow cytometry showed a high heterogeneity of classical T-cell markers within individual patients, with a common cluster of only 5 proteins (S100A4, S100A10, IL7R, CCR7, and CXCR4) [33].

Single-cell RNA sequencing of SS cells suggests also the existence of cases with a shift from a T-regulatory-like phenotype (characterized by FOXP3 expression) to a more central memory phenotype (characterized by the expression of a major Th2 driver - GATA3 or IKZF2) in malignant CD4+ cells [34]. In line with this finding, FOXP3 could be an important factor to predict early disease in CTCL, along with another 19 genes suggested to correlate with different CTCL stages [34]. Nevertheless, the role of Treg cells in the pathogenesis of SS is still controversial [35-37]. Some clinical cases in which CTCL appeared with the phenotype of malignant proliferation of Tregs have been observed [38]. Also, a recent study by Borcherding et al. [34] confirmed the presence of CD25FOXP3 + tumor cells in a subset of SS patients. Of interest, in murine modes, an inadequate CD25 expression guarantees Treg plasticity and their differentiation into a Th phenotype depending on the cytokine milieu [39]. Hence, 
the CD25- FOXP3+ population may be an intermediate state of SS cells as well. Recent analyses suggest a marked decrease in the number of $\mathrm{T}_{\mathrm{CM}}$ following HDAC inhibition [33] which may be attributed to an open chromatin state leading to FOXP3 activation [40].

\section{Antitumor Response and Immune Evasion}

\section{Early-Stage CTCL: Equilibrium Phase}

The patient's immune system has an important influence on the tumor fate. Many MF patients can have indolent disease over years, most likely presenting an equilibrium phase where the adaptive immune response can still control tumor outgrowth [11]. Early-stage skin lesions (stages IA to IIA) are infiltrated by a small number of malignant $\mathrm{T}$ cells surrounded by reactive immune cells, including large numbers of activated CD8+ T cells and $\mathrm{T}$ helper 1 (Th1) cells, resulting in the establishment of cellmediated antitumor responses and secretion of cytotoxic molecules, including the proinflammatory cytokines interferon (IFN)- $\alpha$ and IFN- $\gamma$ (Fig. 1a) [41-46]. In earlystage CTCL, the Th1 phenotype is maintained by the expression of signal transducer and activator of transcription 4 (STAT-4) and interleukin (IL)-12 signaling via JAK2/TYK2 [47].

\section{Advanced-Stage CTCL: Tumor Progression Phase}

The escape from immune recognition can lead to tumor progression as observed in advanced-stage CTCL (stages IIB to IVB) with a large increase in infiltrating tumor $\mathrm{T}$ cells presenting on the skin with plaques and tumors (Fig. 1b). During disease progression, the expression of Th2 markers (e.g., GATA-3) and cytokines (e.g., IL-4, IL-5, and IL-10) increases, whereas the expression of Th1 transcription factors, such as T-cell-specific T-box transcription factor (T-bet), IFN- $\gamma$, STAT4, and IL-12 decreases $[48,49]$. What shifts the balance in favor of tumor progression remains to be largely unknown in CTCL. One contributor might be mutations in the JAK/STAT pathway, making it persistently active in cancer $\mathrm{T}$ cells [49]. In early disease, there is constitutive activation of STAT5; in later disease there is activation of STAT3. STAT-5 via miR-155 reduces STAT4 expression, which is critical for the Th1 phenotype and thereby contributes to a Th1 to Th2 switch [49]. Moreover, STAT5 is known to be involved in the transcription of antiapoptotic proteins (bcl-2 and bcl-xl), cell cycle genes (cyclin D and c-myc), and IL-4 cytokines and its activation could be therefore an important driver of tumor cell proliferation [50,51].
In addition to the dominance of the Th2 phenotype in advanced stage CTCL, several types of immune cells have been shown to contribute to a state of immune evasion of the tumor cells. Among them are subpopulations of dendritic cells (DC; immature CD209/DC-DIGN+ DC) [52] and subpopulations of $\mathrm{CD} 4^{+}$and $\mathrm{CD} 8^{+} \mathrm{T}$ cells with a high expression of immune checkpoint inhibitors [53]. Moreover, as already mentioned, also an impaired IL-12 production by DC contributes to the Th2 switch [54].

A clinical characteristic of advanced stage CTCL encompasses the susceptibility to infections as a consequence of impaired antigen-specific T-cell responses and decreased CD8 cytotoxic response [55]. The susceptibility to infections together with peripheral eosinophilia and high IgE and IgA levels further confirms a Th2-driven immunological process [55]. Interestingly, high IgE to environmental and food allergens in Sézary patients has been associated with a lower survival rate [56]. Therapies targeting the Th2 phenotype that would reinvert it into a Th1 immunological response hold potential for improving both the anticancer and the antipathogen response [41].

The presence and role of natural killer (NK) cells in CTCL skin lesions is still under debate. CTCL cells have been demonstrated to be susceptible to NK-induced killing in vitro [57]. Recently, an analysis of NK cells in peripheral blood showed no significant difference in the number of NK cells in CTCL versus healthy individuals [58]. This is in contrast with previous reports of decreased NK cell numbers in SS patients that suggested that their function may be increased by Toll-like receptor (TLR) stimulation [59]. On the other hand, higher numbers of circulating NK cells have been correlated with a poorer prognosis both in MF and in SS [58] and related to findings in another Th2-mediated disease, i.e., atopic dermatitis (AD), where NK dysregulation contributed to $\mathrm{AD}$ pathogenesis [60]. Although the reason for these findings is not entirely clear, they suggest that the existence of the inhibitory mechanism of the CTCL microenvironment has a significant role in suppressing the anti-tumor activity of NK cells in vivo. One such factors may be chronic IL-15 stimulation leading to an exhaustion state of NK cells, defined as their hyperactivation together with impaired recognition of malignant cells [58]. However, the involvement of NK cells in providing an antitumor response in the skin remains controversial, as NK cells have been described to be present in the skin in scarce amounts $[61,62]$. The effectiveness of rituximab (anti-CD20 mAb) in the therapy of primary cutaneous B-cell lymphoma indicates that NK cells in the skin have valid antibody-de- 
pendent cell-mediated cytotoxicity (ADCC). However, in a phase 3 clinical trial, the reported response rate (RR) of mogamulizumab (anti-CCR4 $\mathrm{mAb}$ ) was only $28 \%$ despite the high CCR4 expression in the study cohort [63]. Also, the RR in the skin was much lower compared blood. Impaired ADCC may also contribute to the inefficacy of anti-CD52 mAb (alemtuzumab) in MF $[64,65]$.

Neutrophils may also contribute to CTCL pathophysiology, as hyperactivated neutrophils are found in peripheral blood of CTCL patients (even in early disease) and the secreted IL-8 and LTB4 contribute to skin inflammation [66]. Moreover, an increased number of myeloidderived suppressor cells (MDSCs) in comparison to healthy subjects has been observed in both MF and SS and a decrease in their numbers has been noted after successful therapy [67-69].

\section{Therapy}

Treatment of CTCL depends on the stage of the disease and the general condition of the patient. Early disease stages of MF (IA-IIA) can be controlled with skin - directed therapy, such as topical steroids, light treatment and radiation $[4,70]$. Systemic treatments, such as retinoids and IFN- $\alpha$ have been recommended as second-line treatment of MF stages IA, IB and IIA [71]. The 5-year survival for these patients is around $90 \%$, significantly better compared with $30 \%-50 \%$ for advanced disease (IIB-IVB) [72]. Chemotherapy agents, such as monochemotherapy (gemcitabine, pegylated liposomal doxorubicine) and polychemotherapy, as well as newer systemic agents (brentuximab-vedotin and mogamulizumab) are recommended in advanced disease stage. Large cell transformation in histology, expression of CD30 and folliculotropic subtype of MF have been reported to have a more aggressive course and poorer prognosis. Although rare cases of $\mathrm{CD}^{-} \mathrm{CD}^{+}, \mathrm{CD}^{-} \mathrm{CD}^{-}$, or $\mathrm{CD} 4^{+} \mathrm{CD} 8^{+}$immunophenotypes have been described in MF, these differences in phenotype do not affected the prognosis of the disease [73]. However, a phenotypic switch from $\mathrm{CD} 4^{+}$to CD4 ${ }^{-}$in the lesion has been suggested a portend of poor outcome [74].

SS is associated with a poor prognosis and overall survival rates varying from 7.5 to 22.4 months [75]. Apart from conventional treatments (e.g. extracorporeal photopheresis (ECP), light treatment (PUVA), retinoids, IFN- $\alpha$, low dose methotrexate and polychemotherapy), smallmolecule inhibitors e.g. histone deacetylase inhibitors (HDACi) and monoclonal antibodies (mAbs) are current- ly being explored as therapeutic options in SS [76, 77]. A comprehensive review on investigative drugs in CTCL has been published recently [78]. Despite their initial moderate to good response to most treatments, SS patients often develop resistance to treatment in the course of the disease [79]. Selection of more robust and aggressive tumor clones has been hypothesized as one possible driver for resistance; e.g. in a small cohort of SS patients, tumor cell subpopulations were heterogeneous and showed different sensitivity to HDACi [33]. Also, although no single common driver mutation has been identified, novel findings demonstrate aberrant functioning of cell division mechanisms in CTCL that lead to genetic instability and possible escape to treatment [80]. Further, the role of STAT3 activation in conferring resistance in both SS and advancedstage MF has become clearer [81, 82]. And finally, SS cells have been shown to display resistance to apoptosis when chromatin remodeling is defect, such as in SNF5- and SATB1-deficient cells, or when Fas-mediated apoptosis is defect $[83,84]$. If and how exactly these mechanisms contribute to treatment resistance in SS cell subpopulations has yet to be addressed in detail. Taken together, despite the numerous systemic treatment options available, long - term remission rates with conventional treatments alone are still low and allogeneic hematopoietic stem cell transplantation (alloHSCT) is currently the only curative option in advanced MF/SS $[85,86]$.

Thorough reviews analyzing the therapeutic options available for CTCL have been lastly identified in the literature $[70,85,87,88]$. Herein, we summarize the recent advances in the immunotherapies of CTCL.

\section{Recent Advances in Immunotherapies of CTCL}

\section{ECP and PUVA}

Both extracorporeal photopheresis (ECP) and psoralen plus ultraviolet A (PUVA) consist of the systemic or local application of 8-metoxypsolaren and subsequent photoactivation resulting in apoptosis of malignant lymphocytes [89-92]. However, despite the established use in the management of CTCL, their mechanism of action is still not sufficiently investigated. While PUVA is applied to patients with earlier stages of CTCL and skin involvement only, ECP is used mainly in erythrodermic patients with blood involvement [93]. PUVA induces remission lasting up to 10 years in $72 \%$ of MF patients $[2,94]$ and is described to have an immunomodulatory effect i.e. a shift from Th2 to Th1 phenotype [95]. A recent study by Vieyra-Garcia et al. [96] shed new light on the mechanisms 
beyond PUVA efficacy in CTCL. The authors have demonstrated a switch from a Th2 with CCL18 overexpression, to a Th1 phenotype characterized by CXCL9, CXCL10, and CXCL11 expression. Moreover, they have shown that while in low-burden disease the efficacy of PUVA results in the reduction of the number of malignant T-cells, in high-burden disease it relies mostly on the recruitment of clonal cytotoxic T cells. The study identified the c-Kit+OX40L+CD40L+DC as the major drivers of inflammation and clonal expansion of malignant $\mathrm{T}$ cells due to their pro-survival impact and suggested targeting c-Kit, OX40, and CD40 signaling may be a novel therapeutic option in the treatment of MF.

ECP induces response rates of approximately 60\%, with complete responses of $14-26 \%[89,97]$ that can be further improved when combined with other immunomodulatory agents, such as IFN- $\alpha$ or systemic retinoids $[89,98]$. The immunomodulatory effect of ECP is thought to rely on the induction of monocyte differentiation to DC that are capable of phagocytosing and efficiently presenting tumor antigens $[99,100]$. Moreover, a shift from Th2 bias to a Th1 proinflammatory phenotype has been reported [90]. Recently, there has been considerable interest in defining the role of NK cells in the success of ECP. Recent studies have reported a significant increase in the percentage of CD56+dim NK cells characterized by a high cytotoxic potential 3 months after the start of therapy [20]. Interestingly, Mundy-Bosse et al. [58] reported that increased NK cell cytotoxicity and higher NK-cell numbers before ECP were associated with decreased short-term survival.

\section{Monoclonal Antibodies}

Mogamulizumab (Anti-CCR4)

Mogamulizumab, a glycol-engineered $\mathrm{mAb}$ targeting chemokine receptor type 4 (CCR4) with an increased affinity to Fc $\gamma$ RIIIa (CD16) and enhanced ADCC [101], was approved in August 2018 for patients with relapsed or refractory, advanced CTCL with at least 1 prior systemic therapy [63]. Apart from the clinical efficacy, patients treated with mogamulizumab reported an improvement in their quality of life, including skin pain and fatigue [63]. Mogamulizumab is generally well-tolerated; however some skin-related toxicities due to the induction of autoantibodies recognizing human keratinocytes or melanocytes that induce complement-dependent cytotoxicity have been reported [102]. Of note, targeting CCR4 may also result in the depletion of nonmalignant Tregs, thus leading to or aggravating autoimmune disorders [103]. In this way, it also increases the risk of graft-versus-host dis- ease following allogeneic bone marrow transplantation [104], which should be therefore delayed by at least 50 days from the administration of the last dose [105].

\section{Immune Checkpoint Inhibitors}

Based on the increased response rates associated with targeting of negative immune regulators through mAbs, also known as immune checkpoints inhibitors (ICI), in a wide spectrum of malignancies, including melanoma, there is considerable interest in applying these targets in the management of CTCL [87]. The particularity of CTCL in the context of implementation of ICI relies on the fact that the tumor itself arises from CD4+ T cells, a population of lymphocytes responsible for priming of the cytotoxic response. Increasing evidence suggests that in CTCL both CD4+ and CD8+ cells have characteristics of immune exhaustion $[53,106,107]$, and therefore targeting immune checkpoints would have implications on the functionality of both helper and cytotoxic $T$ cells. One immune-inhibitory axis is the programmed death (PD-)1 axis, binding to its ligands PD-L1/L2. PD-1 expression has been shown to be high in the blood and skin of SS patients $[108,109]$ and has already been proposed as a factor responsible for drug resistance in SS [110]. A phase 2 clinical trial of the anti-PD1 $\mathrm{mAb}$ pembrolizumab in heavily pretreated advanced-stage MF and SS patients reported an ORR of $38 \%$, with a 1 -year progression-free survival of $69 \%$ and a duration of response of 64 months $[111,112]$. Moreover, there are also ongoing trials targeting PD-L1, using anti-PD-L1 mAbs, i.e., atezolizumab (NCT03357224) and durvalumab (NCT03011814).

A recent analysis investigating $\mathrm{PD}-1$ expression in SS showed a high PD-1 expression on tumor T cells compared to nontumor CD4+ T cells from SS patients or to normal CD4+ cells from healthy individuals [113]. In contrast, PD-L1 showed a decreased expression on tumor T cells, while PD-L2 expression is low and did not show any significant differences between groups. This is in line with other studies [114], where PD-L1 showed a high expression in the tumor environment, particularly in monocyte-derived compartments, where it was expressed by $73 \%$ of cells. Also a recent study by Querfeld et al. [53] showed high PD-L1 levels in DC émigrés from the skin but a low expression by $\mathrm{T}$ cells themselves.

While PD-1/PD-L1 ICI have gained much interest in the therapy of CTCL, much less is known about the expression of other immune receptors. In an analysis of CTCL skin samples, Querfeld et al. [53] observed a higher expression of CTLA-4 on both CD4+ and CD8+ T 
cells. In another study no significant differences were found in CTLA-4 expression in CD4+ malignant versus bystander $\mathrm{T}$ cells in SS patients and healthy controls [115]. However, as the combination of anti-PD-1 (nivolumab) with anti-CTLA-4 showed no benefit compared to nivolumab alone [116], there are no active or recruiting clinical studies testing the efficacy of CTLA-4 targeting in CTCL. A recent analysis [115] of a panel of checkpoint inhibitors in a small cohort of SS patients revealed a significant upregulation of FRCL3 and TIGIT expression, which is in line with the previous reports $[117,118]$, together with a reduced expression of LAG-3 on CD4+ tumor cells. As several advanced clinical studies address TIGIT as a target molecule, it may also be of interest in CTCL. Interestingly Querfeld et al. [53] observed increased LAG-3 expression in lesional MF skin samples, which may be explained by the fact that MF and SS arise from distinct T-cell subsets [7]. Further, a hitherto nondemonstrated overexpression of BTLA on CD4+ cells in SS has been reported [115]. This is of possible interest, as BTLA blockade would arrest T-cell proliferation and can be therapeutically targeted by a specific fragment (HVEM 26-28) [119]. However, no in vivo studies have been conducted so far. As immune checkpoints have nonredundant roles in cancer progression, other emerging regulatory molecules (TIM-3, CD96 [TACTILE], and PD-1H [VISTA]) may be of interest in CTCL, too.

\section{CD47}

CD47 is highly expressed on Sézary cells in the peripheral blood and skin and correlates with a worse overall survival [120]. Inhibiting the binding of CD47 to its ligand, SIRPa activates both innate and adaptive antitumor responses by promoting phagocytosis and subsequent activation of CD8+ T cells [reviewed in 121]. Targeting CD47 with TTI-621 not only blocks the "do-not-eat-me signal" of CD47 but it also enhances phagocytosis of tumor cells by monocytes. The data gained in 2 phase I trials suggest its satisfactory activity combined with a good safety profile [120, 122].

\section{Alemtuzumab (Anti-CD52)}

Alemtuzumab is a monoclonal $\mathrm{Ab}$ directed against the surface glycoprotein CD52. CD52 expression on malignant $\mathrm{T}$ cells has been shown in 14 out of 16 CTCL cases by flow cytometry [123]. In several clinical studies, alemtuzumab appears to reach better responses in Sézary patients, with an ORR of $81 \%$, as compared to MF patients, with an ORR of 29\% [124]. A retrospective study of 39 advanced CTCL patients also showed long-term remis- sion in Sézary patients but not in MF patients [65]. The treatment is associated with a high toxicity, but this can be lowered by subcutaneous administration (as compared to intravenous) and lower doses of the antibody. Despite a good response rate in Sézary patients, it is not approved anymore for CTCL treatment. Currently, there is an ongoing phase I study using a combination treatment of IL-15 and alemtuzumab in different T-cell leukemia and lymphoma conditions (NCT02689453).

\section{KIR3DL2 Targeting}

KIR3DL2, also called CD158k, is overexpressed by transformed advanced MF and SS cells correlating with the disease stage and large cell transformation [125] as well as a shorter survival [126]. IPH4102, an anti-KIR2DL2 humanized IgG1 mAb, effectively induces ADCC and immunophagocytosis [127], delays tumor growth, and improved the overall survival in a xenograft mouse model. The results of a phase I study in MF and SS patients (NCT02593045) demonstrated a confirmed global overall response in 16 of 44 patients (36.4\%; 95\% CI 23.8-51.1), and, of those, 15 responses were observed in 35 patients with SS (43\%; 95\% CI 28.0-59.1) [128]. Moreover, a phase II trial of IPH4102 alone or in combination with chemotherapy in patients with advanced T-cell lymphoma (TELLOMAK) (NCT03902184) is currently recruiting.

\section{Chimeric Antigen Receptor-Based Therapies}

Given their success in the treatment of B-cell malignancies, chimeric antigen receptor (CAR)-modified lymphocytes raise interest as a therapeutic option in CTCL. However, their use poses some considerable issues. First of all, there is a lack of specific targets expressed uniquely on malignant $\mathrm{T}$ cells. This results in 2 different concerns. One is that, when using a specific target for a tumor (sub)population, not all malignant cells are affected by the treatment and relapse of the disease occurs. The other is that, when using a more broadly expressed marker, targeting also of healthy $\mathrm{T}$ cells can occur, which can lead to life-threatening T-cell aplasia. While the first concern is difficult to solve, unless a unique marker expressed by all malignant cells is discovered, the second concern could be overcome by a transient CAR expression or expression of suicide genes allowing for reconstitution of T cells. By now CD4, CD5, CD7, CD30, CD37, CCR4, and TCR $\beta$ chains (TRBC1/ TRBC2) have been tested as possible targets of CARbased therapies [reviewed in 129]. An alternative to targeting T cells is the application of CAR-transduced NK cells. This may offer an alternative as it eliminates the 
phenomenon of fratricide, i.e., mutual killing of CARexpressing cells due to shared T-cell antigens [129].

\section{Cytokines}

\section{Interferons}

Next to IFN- $\alpha$, which is an approved and recommended treatment for MF and SS [130], IFN- $\gamma$ has emerged as a novel option for the patients who have failed IFN- $\alpha$. IFN- $\gamma$ abrogates the Th1/Th2 bias inducing a Th1-dominated tumor microenvironment and stimulates macrophages, DC, and cytotoxicity, mediated by CD8 T cells and NK cells [131]. As demonstrated by a small-scale study by Kaplan et al. [132], who treated $16 \mathrm{MF}$ and SS patients with IFN- $\gamma$, $31 \%$ of patients had an objective partial response. None of the patients showed a complete response. A subsequent small-dose-escalating study by Dummer et al. [133] demonstrated the therapeutic effect of intratumoral injections of TG1042 (a third-generation, nonreplicating human adenovirus vector containing a human IFN $-\gamma \mathrm{cDNA}$ insert). The observations included 9 patients (CTCL, $n=7$; CBCL, $n=2$ ) injected with the following doses of TG1042:3 $310^{9}$, $3 \times 10^{10}$, and $3 \times 10^{11}$ total particles. A local clinical response was observed in 5 of the 9 treated patients ( 3 patients with a complete response and 2 patients with a partial response). Three patients reported a complete systemic response, represented by clearance of noninjected skin lesions. The duration of the clinical response was on average 3 months (range 1-6 months) and only grade 1 and 2 adverse events were reported [133].

\section{Interleukin-12}

IL-12 is a Th1-promoting cytokine produced by the antigen-presenting cells. It is a potent inducer of IFN- $\gamma$. IL-12 boosts NK cell activity and cytotoxic T-cell responses in CTCL [134]. As discussed before, a Th2-dominant cytokine milieu and a reduced production of Th1inducing cytokines such as IFN- $\gamma$ and IL-12 are a hallmark of immune evasion in advanced MF and SS [135]. In vitro data have shown increased lysis of malignant cells derived from SS patients when cultured with IL-12, providing additional evidence of the role of cytokines in antitumor immune function [134]. The therapeutic effect of IL-12 administration was tested in a small-scale $(n=10)$ phase I trial using 50-300 ng/kg IL-12. The study cohort included patients with MF and SS, stages T1 to T4. Unfortunately, the observations in SS patients were scarce because 2 of the 3 SS patients withdrew from the treatment. Overall, $20 \%$ of the patients showed a complete response, $20 \%$ showed a partial response, and the remaining patients had no response or a local response.

\section{TLR Agonists}

TLR are key players in innate immunity. TLR are predominantly expressed by DC and macrophages and recognize pathogen antigens in the microenvironment [136]. Once bound to their ligand, they induce antigen presentation and cell proliferation and cause surface upregulation of costimulatory molecules on the antigen-presenting cells, leading to $\mathrm{T}$ cell activation and increased cytotoxicity [137]. The therapeutic targets addressed in CTCL are TLR7 and TLR8, which bind viral RNA particles, and TLR9, which binds bacterial and viral DNA.

\section{Imiquimod (TLR 7 Agonist)}

TLR7 is expressed on plasmacytoid DC (pDC) [138]. Targeting TLR7 with a synthetic ligand, i.e., imiquimod, induces the production of proinflammatory cytokines, i.e. IFN- $\alpha$, which induces a Th1 type immune response and shift towards cell-mediated immunity. There are several case reports and case series describing the efficacy of imiquimod treatment in CTCL patients [139-145]. Summarized results of the studies demonstrate that $71 \%$ of the patients have a complete response and $17 \%$ stable disease. Despite the promising results, imiquimod is not approved for use in CTCL because larger trials are necessary to evaluate its efficacy and safety in MF and SS.

\section{Resiquimod (TLR7 and TLR8 Agonist)}

Resiquimod binds to both TLR7 and TLR8. Despite their structural similarity, the 2 receptors differ in their signaling, and their activation leads to secretion of different cytokines. The TLR7 agonist activates predominantly $\mathrm{pDC}$, inducing the production of IFN- $\alpha$ and IFN-regulated chemokines such as IFN-inducible protein and IFN-inducible T-cell $a$ chemoattractant. The TLR8 agonist activates $\mathrm{mDC}$, monocytes, and MDC to secrete TNF- $\alpha$, IL-12, and MIP-1 $\alpha$ [146]. In summary, TLR7 activation results in a 5-10 times greater production of IFN- $\alpha$, whereas TLR7/8 stimulation increases TNF- $\alpha$ and IL-12 levels approximately 10 times. A phase I clinical trial with 12 early-stage patients (from IA to IIA MF) illustrated a $17 \%$ complete response rate and a $75 \%$ partial response rate in patients. Moreover, the dose escalation correlates with a better response [147]. The elevated after-treatment levels of TNF- $\alpha$, IL-12, and IFN- $\gamma$ induce the cytotoxic function of CD8 and NK cells and partial or complete reduction of the clonal malignant $\mathrm{T}$ cells in skin biopsies and correlate positively with treatment response.
Bobrowicz/Fassnacht/Ignatova/Chang/ Dimitriou/Guenova 


\section{TLR9 Agonist}

TLR9 is an intracellular receptor expressed on numerous immune cells and it is activated by unmethylated CpG sequences found in bacterial or viral DNA. Its binding initiates the release of proinflammatory cytokines such as type I IFN and IL-12 [148]. In a phase $1 / 2$ study by Kim et al. [149] $15 \mathrm{MF}$ patients received intratumoral injections with TLR9 agonist CpG oligodeoxynucleotides combined with localized radiation. The combination of TLR9 agonist treatment and radiation was chosen because local radiation increases the number of available tumor antigens for $\mathrm{pDC}$, which in parallel are primed by unmethylated $\mathrm{CpG}$ sequences. The overall response rate is approximately $36 \%$ with a median response duration of 7 weeks.

\section{Antibiotics}

A diminished diversity of skin microbiome with a tendency toward increased colonization with SA has been reported in both MF and SS [150, 151]. It has been suggested that SA enterotoxins stimulate a reciprocal cross-talk between nonmalignant and malignant $\mathrm{T}$ cells resulting in IL2-dependent proliferation of the malignant clone [152] and that interaction of $\mathrm{T}$ cells with the bacterial microenvironment may accelerate disease progression by promoting STAT signaling [153]. Thus, microbiome targeting may be a therapeutic strategy. Indeed, a recent small clinical study by Lindahl et al. [154] demonstrated that a shortterm aggressive treatment with a SA-targeting antibiotic regimen resulted in a marked long-lasting clinical improvement in advanced-stage CTCL patients [154], leading to a decrease in the proliferation of malignant cells, STAT3 signaling, and the expression of CD25. These observations encourage the conduction of studies combining the targeting of SA together with STAT signaling [155].

\section{Outlook}

CTCL is a rare skin lymphoma arising from malignant T-cell homing to or sessile in the skin. Both intrinsic and extrinsic factors may play a critical role in the pathophysiology of CTCL and cutting-edge research is currently focused on how increased levels and/or overactivation of key molecules, such as STAT3, GATA3, CCR4, and KIR3DL2, contribute to the initiation and progression of the disease. The extensive research performed in recent years has greatly advanced our understanding of CTCL and its impact on patient care and quality of life.

Naturally occurring molecules and genes, involved directly in or acting as surrogate parameters for active pathophysiological disease processes, if easily detectable, are convenient for use as biomarkers, disease-classifying molecules, or treatment targets. However, the heterogeneity of CTCL renders the detection of common markers and/or therapeutic targets difficult. Novel technologies and large-scale data generation combined with analytical approaches supported by artificial intelligence are expected to deliver the necessary knowledge and allow personalized medicine for the domain of CTCL.

The rarity of the diseases of the CTCL group necessitates an international collaborative effort to successfully accomplish high-evidence clinical research. In the last few years, the set-up has been established and successfully applied for at least 2 large prospective randomized clinical trials.

\section{Conflict of Interest Statement}

F.D. has received intermittent travel support from Pierre Fabre outside of this work. E.G. has intermittent, project-focused consulting and/or advisory relationships with Mallinckrodt, Takeda, Helsinn, Scaylite, and Novartis outside of this work. M.B., C.F., D.I., and Y.-T.C. declare no conflict of interests.

\section{Funding Sources}

This project was supported by the Jubiläumsstiftung von SwissLife, the Promedica Stiftung (1406/M and 1412/M), a further anonymous foundation, the Swiss Cancer Research Foundation (KFS-4243-08-2017), the Clinical Research Priority Program (CRPP) of the University of Zurich, the Swiss National Science Foundation (PMPDP3_151326), and the European Academy of Dermatology and Venereology (PPRC-2019-20). The funders had no role in the study design, data collection and analysis, the decision to publish, or the preparation of this paper.

\section{Author Contributions}

All of the authors searched for and collected literature data and participated in the writing and approved the final version of this paper.

References

1 Kempf W, Zimmermann AK, Mitteldorf C. Cutaneous lymphomas-An update 2019. Hematol Oncol. 2019 Jun;37(S1 Suppl 1):43-7.

2 Willemze R, Cerroni L, Kempf W, Berti E, Facchetti F, Swerdlow SH, et al. The 2018 update of the WHO-EORTC classification for primary cutaneous lymphomas. Blood. 2019 Apr;133(16):1703-14.

3 Ferenczi K, Makkar HS. Cutaneous lymphoma: kids are not just little people. Clin Dermatol. 2016 Nov - Dec;34(6):749-59. 
4 Wilcox RA. Cutaneous T-cell lymphoma: 2017 update on diagnosis, risk-stratification, and management. Am J Hematol. 2017 Oct; 92(10):1085-102.

5 Willemze R, Jaffe ES, Burg G, Cerroni L, Berti E, Swerdlow SH, et al. WHO-EORTC classification for cutaneous lymphomas. Blood. 2005 May; 105(10):3768-85.

6 Geller S, Myskowski PL, Pulitzer M, Horwitz SM, Moskowitz AJ. Cutaneous T-cell lymphoma (CTCL), rare subtypes: five case presentations and review of the literature. Linchuang Zhongliuxue Zazhi. 2019 Feb;8(1):5

7 Campbell JJ, Clark RA, Watanabe R, Kupper TS. Sezary syndrome and mycosis fungoides arise from distinct T-cell subsets: a biologic rationale for their distinct clinical behaviors. Blood. 2010 Aug;116(5):767-71.

8 Larocca C, Kupper T. Mycosis Fungoides and Sézary Syndrome: an Update. Hematol Oncol Clin North Am. 2019 Feb;33(1):103-20.

9 Serrano L, Martinez-Escala ME, Zhou XA, Guitart J. Pruritus in Cutaneous T-Cell Lymphoma and Its Management. Dermatol Clin. 2018 Jul;36(3):245-58.

10 Demierre MF, Gan S, Jones J, Miller DR. Significant impact of cutaneous T-cell lymphoma on patients' quality of life: results of a 2005 National Cutaneous Lymphoma Foundation Survey. Cancer. 2006 Nov;107(10):2504-11.

11 Scarisbrick JJ, Quaglino P, Prince HM, Papadavid E, Hodak E, Bagot M, et al. The PROCLIPI international registry of early-stage mycosis fungoides identifies substantial diagnostic delay in most patients. Br J Dermatol. 2019 Aug;181(2):350-7.

12 Mourad A, Gniadecki R. Overall Survival in Mycosis Fungoides: A Systematic Review and Meta-Analysis. J Invest Dermatol. 2020 Feb; 140(2):495-497.e5.

13 Talpur R, Singh L, Daulat S, Liu P, Seyfer S, Trynosky T, et al. Long-term outcomes of 1,263 patients with mycosis fungoides and Sézary syndrome from 1982 to 2009. Clin Cancer Res. 2012 Sep;18(18):5051-60.

14 Mangold AR, Thompson AK, Davis MD, Saulite I, Cozzio A, Guenova E, et al. Early clinical manifestations of Sézary syndrome: A multicenter retrospective cohort study. J Am Acad Dermatol. 2017 Oct;77(4):719-27.

15 Whittemore AS, Holly EA, Lee IM, Abel EA, Adams RM, Nickoloff BJ, et al. Mycosis fungoides in relation to environmental exposures and immune response: a case-control study. J Natl Cancer Inst. 1989 Oct;81(20): 1560-7.

16 Netchiporouk E, Gantchev J, Tsang M, Thibault P, Watters AK, Hughes JM, et al. Analysis of CTCL cell lines reveals important differences between mycosis fungoides/ Sézary syndrome vs. HTLV-1+ leukemic cell lines. Oncotarget. 2017 Oct;8(56):95981-98.

17 Jahan-Tigh RR, Huen AO, Lee GL, Pozadzides JV, Liu P, Duvic M. Hydrochlorothiazide and cutaneous $\mathrm{T}$ cell lymphoma: prospective analysis and case series. Cancer. 2013 Feb;119(4):825-31.
18 Jackow CM, McHam JB, Friss A, Alvear J, Reveille JR, Duvic M. HLA-DR5 and DQB1*03 class II alleles are associated with cutaneous T-cell lymphoma. J Invest Dermatol. 1996 Sep;107(3):373-6.

19 Choi J, Goh G, Walradt T, Hong BS, Bunick CG, Chen K, et al. Genomic landscape of cutaneous T cell lymphoma. Nat Genet. 2015 Sep;47(9):1011-9.

20 da Silva Almeida AC, Abate F, Khiabanian H, Martinez-Escala E, Guitart J, Tensen CP, et al. The mutational landscape of cutaneous $\mathrm{T}$ cell lymphoma and Sézary syndrome. Nat Genet. 2015 Dec;47(12):1465-70

21 Park J, Yang J, Wenzel AT, Ramachandran A, Lee WJ, Daniels JC, et al. Genomic analysis of 220 CTCLs identifies a novel recurrent gainof-function alteration in RLTPR (p.Q575E). Blood. 2017 Sep;130(12):1430-40.

22 Wang L, Ni X, Covington KR, Yang BY, Shiu J, Zhang X, et al. Genomic profiling of Sézary syndrome identifies alterations of key $\mathrm{T}$ cell signaling and differentiation genes. Nat Genet. 2015 Dec;47(12):1426-34.

23 McGirt LY, Jia P, Baerenwald DA, Duszynski RJ, Dahlman KB, Zic JA, et al. Whole-genome sequencing reveals oncogenic mutations in mycosis fungoides. Blood. 2015 Jul;126(4): 508-19.

24 Ungewickell A, Bhaduri A, Rios E, Reuter J, Lee CS, Mah A, et al. Genomic analysis of mycosis fungoides and Sézary syndrome identifies recurrent alterations in TNFR2. Nat Genet. 2015 Sep;47(9):1056-60.

25 Woollard WJ, Pullabhatla V, Lorenc A, Patel VM, Butler RM, Bayega A, et al. Candidate driver genes involved in genome maintenance and DNA repair in Sézary syndrome. Blood. 2016 Jun;127(26):3387-97.

26 Guenova E, Metzler G, Hoetzenecker W, Berneburg M, Rocken M. Classic Mediterranean Kaposi's sarcoma regression with sirolimus treatment. Arch Dermatol. 2008 May;144(5): 692-3.

27 Blümel E, Munir Ahmad S, Nastasi C, Willerslev-Olsen A, Gluud M, Fredholm S, et al. Staphylococcus aureus alpha-toxin inhibits CD8+ T cell-mediated killing of cancer cells in cutaneous T-cell lymphoma. OncoImmunology. 2020 Apr;9(1):1751561.

28 Ghazawi FM, Alghazawi N, Le M, Netchiporouk E, Glassman SJ, Sasseville D, et al. Environmental and other extrinsic risk factors contributing to the pathogenesis of cutaneous T cell lymphoma (CTCL). Front Oncol. 2019 Apr;9:300.

29 Clark RA. Skin-resident T cells: the ups and downs of on site immunity. J Invest Dermatol. 2010 Feb;130(2):362-70.

30 van Doorn R, van Kester MS, Dijkman R, Vermeer MH, Mulder AA, Szuhai K, et al. Oncogenomic analysis of mycosis fungoides reveals major differences with Sezary syndrome. Blood. 2009 Jan;113(1):127-36.

31 Laharanne E, Oumouhou N, Bonnet F, Carlotti M, Gentil C, Chevret E, et al. Genomewide analysis of cutaneous $\mathrm{T}$-cell lymphomas identifies three clinically relevant classes. J Invest Dermatol. 2010 Jun;130(6):1707-18.

32 Roelens M, Delord M, Ram-Wolff C, MarieCardine A, Alberdi A, Maki G, et al. Circulating and skin-derived Sézary cells: clonal but with phenotypic plasticity. Blood. 2017 Sep; 130(12):1468-71.

33 Buus TB, Willerslev-Olsen A, Fredholm S, Blümel E, Nastasi C, Gluud M, et al. Singlecell heterogeneity in Sézary syndrome. Blood Adv. 2018 Aug;2(16):2115-26.

34 Borcherding N, Voigt AP, Liu V, Link BK, Zhang W, Jabbari A. Single-cell profiling of cutaneous T-cell lymphoma reveals underlying heterogeneity associated with disease progression. Clin Cancer Res. 2019 May;25(10): 2996-3005.

35 Heid JB, Schmidt A, Oberle N, Goerdt S, Krammer PH, Suri-Payer E, et al. FOXP3+ CD25- tumor cells with regulatory function in Sézary syndrome. J Invest Dermatol. 2009 Dec;129(12):2875-85.

36 Tiemessen MM, Mitchell TJ, Hendry L, Whittaker SJ, Taams LS, John S. Lack of suppressive $\mathrm{CD} 4+\mathrm{CD} 25+\mathrm{FOXP} 3+\mathrm{T}$ cells in advanced stages of primary cutaneous $\mathrm{T}$-cell lymphoma. J Invest Dermatol. 2006 Oct; 126(10):2217-23.

37 Gjerdrum LM, Woetmann A, Odum N, Burton CM, Rossen K, Skovgaard GL, et al. FOXP3+ regulatory $\mathrm{T}$ cells in cutaneous $\mathrm{T}$ cell lymphomas: association with disease stage and survival. Leukemia. 2007 Dec; 21(12):2512-8

38 Berger CL, Tigelaar R, Cohen J, Mariwalla K, Trinh J, Wang N, et al. Cutaneous T-cell lymphoma: malignant proliferation of T-regulatory cells. Blood. 2005 Feb;105(4):1640-7.

39 Komatsu N, Mariotti-Ferrandiz ME, Wang Y, Malissen B, Waldmann H, Hori S. Heterogeneity of natural Foxp3+ T cells: a committed regulatory $\mathrm{T}$-cell lineage and an uncommitted minor population retaining plasticity. Proc Natl Acad Sci USA. 2009 Feb;106(6):1903-8.

40 Qu K, Zaba LC, Satpathy AT, Giresi PG, Li R, Jin $Y$, et al. Chromatin accessibility landscape of cutaneous $\mathrm{T}$ cell lymphoma and dynamic response to HDAC inhibitors. Cancer Cell. 2017;32(1):27-41 e4.

41 Guenova E, Watanabe R, Teague JE, Desimone JA, Jiang Y, Dowlatshahi M, et al. TH2 cytokines from malignant cells suppress TH1 responses and enforce a global $\mathrm{TH} 2$ bias in leukemic cutaneous T-cell lymphoma. Clin Cancer Res. 2013 Jul;19(14):3755-63.

42 Wood GS, Edinger A, Hoppe RT, Warnke RA. Mycosis fungoides skin lesions contain CD8+ tumor-infiltrating lymphocytes expressing an activated, MHC-restricted cytotoxic T-lymphocyte phenotype. J Cutan Pathol. 1994 Apr;21(2):151-6.

43 Asadullah K, Friedrich M, Döcke WD, Jahn S, Volk HD, Sterry W. Enhanced expression of T-cell activation and natural killer cell antigens indicates systemic anti-tumor response in early primary cutaneous T-cell lymphoma. J Invest Dermatol. 1997 May;108(5):743-7. 
44 Bagot M, Echchakir H, Mami-Chouaib F, Delfau-Larue MH, Charue D, Bernheim A, et al. Isolation of tumor-specific cytotoxic $\mathrm{CD} 4+$ and CD4+CD8dim+ T-cell clones infiltrating a cutaneous T-cell lymphoma. Blood. 1998 Jun;91(11):4331-41.

45 Echchakir H, Bagot M, Dorothée G, Martinvalet $\mathrm{D}$, Le Gouvello $\mathrm{S}$, Boumsell $\mathrm{L}$, et al. Cutaneous $\mathrm{T}$ cell lymphoma reactive $\mathrm{CD} 4+$ cytotoxic T lymphocyte clones display a Th1 cytokine profile and use a fas-independent pathway for specific tumor cell lysis. J Invest Dermatol. 2000 Jul;115(1):74-80.

46 Hsi AC, Lee SJ, Rosman IS, Carson KR, Kelley A, Viele V, et al. Expression of helper T cell master regulators in inflammatory dermatoses and primary cutaneous $\mathrm{T}$-cell lymphomas: diagnostic implications. J Am Acad Dermatol. 2015 Jan;72(1):159-67.

47 Showe LC, Fox FE, Williams D, Au K, Niu Z, Rook AH. Depressed IL-12-mediated signal transduction in $\mathrm{T}$ cells from patients with Sezary syndrome is associated with the absence of IL-12 receptor beta 2 mRNA and highly reduced levels of STAT4. J Immunol. 1999;163(7):4073-9.

48 Vowels BR, Lessin SR, Cassin M, Jaworsky C, Benoit B, Wolfe JT, et al. Th2 cytokine mRNA expression in skin in cutaneous T-cell lymphoma. J Invest Dermatol. 1994 Nov;103(5): 669-73.

49 Netchiporouk E, Litvinov IV, Moreau L, Gilbert M, Sasseville D, Duvic M. Deregulation in STAT signaling is important for cutaneous T-cell lymphoma (CTCL) pathogenesis and cancer progression. Cell Cycle. 2014;13(21): 3331-5.

50 Qin JZ, Kamarashev J, Zhang CL, Dummer R, Burg G, Döbbeling U. Constitutive and interleukin-7- and interleukin-15-stimulated DNA binding of STAT and novel factors in cutaneous $\mathrm{T}$ cell lymphoma cells. J Invest Dermatol. 2001 Sep;117(3):583-9.

51 Litvinov IV, Pehr K, Sasseville D. Connecting the dots in cutaneous $\mathrm{T}$ cell lymphoma (CTCL): STAT5 regulates malignant $\mathrm{T}$ cell proliferation via miR-155. Cell Cycle. 2013 Jul;12(14):2172-3.

52 Schlapbach C, Ochsenbein A, Kaelin U, Hassan AS, Hunger RE, Yawalkar N. High numbers of DC-SIGN+ dendritic cells in lesional skin of cutaneous T-cell lymphoma. J Am Acad Dermatol. 2010 Jun;62(6):9951004.

53 Querfeld C, Leung S, Myskowski PL, Curran SA, Goldman DA, Heller G, et al. Primary T Cells from Cutaneous T-cell Lymphoma Skin Explants Display an Exhausted Immune Checkpoint Profile. Cancer Immunol Res. 2018 Aug;6(8):900-9.

54 Wysocka M, Zaki MH, French LE, Chehimi J, Shapiro M, Everetts SE, et al. Sézary syndrome patients demonstrate a defect in dendritic cell populations: effects of CD40 ligand and treatment with GM-CSF on dendritic cell numbers and the production of cytokines. Blood. 2002 Nov;100(9):3287-94.
55 Rook AH, Heald P. The immunopathogenesis of cutaneous T-cell lymphoma. Hematol Oncol Clin North Am. 1995 Oct;9(5):997-1010.

56 Scala E, Abeni D, Palazzo P, Liso M, Pomponi D, Lombardo G, et al. Specific IgE toward allergenic molecules is a new prognostic marker in patients with Sézary syndrome. Int Arch Allergy Immunol. 2012;157(2):159-67.

57 Bouaziz JD, Ortonne N, Giustiniani J, Schiavon V, Huet D, Bagot M, et al. Circulating natural killer lymphocytes are potential cytotoxic effectors against autologous malignant cells in sezary syndrome patients. J Invest Dermatol. 2005 Dec;125(6):1273-8.

58 Mundy-Bosse B, Denlinger N, McLaughlin E, Chakravarti N, Hwang S, Chen L, et al. Highly cytotoxic natural killer cells are associated with poor prognosis in patients with cutaneous T-cell lymphoma. Blood Adv. 2018 Aug; 2(15):1818-27.

59 ManfrereC KC, Torrealba MP, Miyashiro DR, Pereira NZ, Yoshikawa FS, de M Oliveira $\mathrm{L}$, et al. Profile of differentially expressed Tolllike receptor signaling genes in the natural killer cells of patients with Sézary syndrome. Oncotarget. 2017 Sep;8(54):92183-94.

60 Mack MR, Brestoff JR, Niu H, Whelan TM, Oetjen LK, Bodet ND, et al. Natural killer cell dysregulation underlies atopic dermatitis. J Immunol. 2018;200(1 Supplement):45.37-45.37.

61 Batista MD, Ho EL, Kuebler PJ, Milush JM, Lanier LL, Kallas EG, et al. Skewed distribution of natural killer cells in psoriasis skin lesions. Exp Dermatol. 2013 Jan;22(1):64-6.

62 von Bubnoff $\mathrm{D}$, Andrès E, Hentges $\mathrm{F}$, Bieber T, Michel T, Zimmer J. Natural killer cells in atopic and autoimmune diseases of the skin. J Allergy Clin Immunol. 2010 Jan;125(1):60-8.

63 Kim YH, Bagot M, Pinter-Brown L, Rook AH, Porcu P, Horwitz SM, et al.; MAVORIC Investigators. Mogamulizumab versus vorinostat in previously treated cutaneous T-cell lymphoma (MAVORIC): an international, open-label, randomised, controlled phase 3 trial. Lancet Oncol. 2018 Sep;19(9):1192-204.

64 Clark RA, Watanabe R, Teague JE, Schlapbach C, Tawa MC, Adams N, et al. Skin effector memory $\mathrm{T}$ cells do not recirculate and provide immune protection in alemtuzumabtreated CTCL patients. Sci Transl Med. 2012 Jan;4(117):117ra7.

65 de Masson A, Guitera P, Brice P, Moulonguet I, Mouly F, Bouaziz JD, et al. Long-term efficacy and safety of alemtuzumab in advanced primary cutaneous $\mathrm{T}$-cell lymphomas. $\mathrm{Br} \mathrm{J}$ Dermatol. 2014 Mar;170(3):720-4.

66 Goddard DS, Yamanaka K, Kupper TS, Jones DA. Activation of neutrophils in cutaneous T-cell lymphoma. Clin Cancer Res. 2005 Dec; 11(23):8243-9.

67 Hergott CB, Dudley G, Dorfman DM. Circulating myeloid-derived suppressor cells reflect mycosis fungoides/Sezary syndrome disease stage and response to treatment. Blood. 2018;132 Suppl 1:4127.

68 Pileri A, Agostinelli C, Quaglino P, Patrizi A, Pimpinelli N. The role of myeloid derived sup- pressor cells in mycosis fungoides. Cancer Immunol Immunother. 2018 Jul;67(7):1175-6.

69 Geskin LJ, Akilov OE, Kwon S, Schowalter M, Watkins S, Whiteside TL, et al. Therapeutic reduction of cell-mediated immunosuppression in mycosis fungoides and Sézary syndrome. Cancer Immunol Immunother. 2018 Mar;67(3):423-34.

70 Lovgren ML, Scarisbrick JJ. Update on skin directed therapies in mycosis fungoides. Linchuang Zhongliuxue Zazhi. 2019 Feb;8(1):7.

71 Trautinger F, Eder J, Assaf C, Bagot M, Cozzio A, Dummer R, et al. European Organisation for Research and Treatment of Cancer consensus recommendations for the treatment of mycosis fungoides/Sézary syndrome: update 2017. Eur J Cancer. 2017 May;77:57-74.

72 Scarisbrick JJ, Prince HM, Vermeer $\mathrm{MH}$, Quaglino P, Horwitz S, Porcu P, et al. Cutaneous Lymphoma International Consortium Study of Outcome in Advanced Stages of Mycosis Fungoides and Sézary Syndrome: Effect of Specific Prognostic Markers on Survival and Development of a Prognostic Model. J Clin Oncol. 2015 Nov;33(32):3766-73.

73 Jaque A, Mereniuk A, Walsh S, Shear NH, Sade S, Zagorski B, et al. Influence of the phenotype on mycosis fungoides prognosis, a retrospective cohort study of 160 patients. Int J Dermatol. 2019 Aug;58(8):933-9.

74 Marks E, Shi Y, Wang Y. Two cases of phenotypic switch of primary cutaneous $\mathrm{T}$ cell lymphoma after treatment with an aggressive course and review of the literature. Virchows Arch. 2019 Nov;475(5):637-48.

75 Janiga J, Kentley J, Nabhan C, Abdulla F. Current systemic therapeutic options for advanced mycosis fungoides and Sézary syndrome. Leuk Lymphoma. 2018 Mar;59(3):562-77.

76 Guenova E, Hoetzenecker W, Rozati S, Levesque MP, Dummer R, Cozzio A. Novel therapies for cutaneous T-cell lymphoma: what does the future hold? Expert Opin Investig Drugs. 2014 Apr;23(4):457-67.

77 Saulite I, Hoetzenecker W, Weidinger S, Cozzio A, Guenova E, Wehkamp U. Sézary syndrome and atopic dermatitis: comparison of immunological aspects and targets. BioMed Res Int. 2016;2016:9717530.

78 Ramelyte E, Dummer R, Guenova E. Investigative drugs for the treatment of cutaneous $\mathrm{T}$ cell lymphomas (CTCL): an update. Expert Opin Investig Drugs. 2019 Sep;28(9):799-809.

79 Alpdogan O, Kartan S, Johnson W, Sokol K, Porcu P. Systemic therapy of cutaneous T-cell lymphoma (CTCL). Linchuang Zhongliuxue Zazhi. 2019 Feb;8(1):10.

80 Tsang M, Gantchev J, Netchiporouk E, Moreau L, Ghazawi FM, Glassman S, et al. A study of meiomitosis and novel pathways of genomic instability in cutaneous T-cell lymphomas (CTCL). Oncotarget. 2018 Dec; 9(102):37647-61

81 Perez C, Mondejar R, Garcia-Diaz N, Cereceda L, Leon A, Montes S, et al. Advanced-stage mycosis fungoides: role of STAT3, NFKB and NFAT pathways. Br J Dermatol. 2019. 
82 Butler RM, McKenzie RC, Jones CL, Flanagan CE, Woollard WJ, Demontis M, et al. Contribution of STAT3 and RAD23B in Primary Sézary Cells to Histone Deacetylase Inhibitor FK228 Resistance. J Invest Dermatol. 2019 Sep;139(9):1975-1984.e2.

83 Li Y, Wang J, Yu M, Wang Y, Zhang H, Yin J, et al. SNF5 deficiency induces apoptosis resistance by repressing SATB1 expression in Sézary syndrome. Leuk Lymphoma. 2018 Oct;59(10):2405-13.

84 Contassot E, French LE. Epigenetic causes of apoptosis resistance in cutaneous $\mathrm{T}$-cell lymphomas. J Invest Dermatol. 2010 Apr;130(4): 922-4.

85 Johnson WT, Mukherji R, Kartan S, Nikbakht $\mathrm{N}$, Porcu P, Alpdogan O. Allogeneic hematopoietic stem cell transplantation in advanced stage mycosis fungoides and Sézary syndrome: a concise review. Linchuang Zhongliuxue Zazhi. 2019 Feb;8(1):12.

86 Doerschner M, Pekar-Lukacs A, MesserliOdermatt O, Dommann-Scherrer C, Rütti M, Müller AM, et al. Interferon alfa-2a maintenance after salvage autologous stem cell transplantation in atypical mycosis fungoides with central nervous system involvement. Br J Dermatol. 2019 Dec;181(6):1296-302.

87 Shalabi D, Bistline A, Alpdogan O, Kartan S, Mishra A, Porcu P, et al. Immune evasion and current immunotherapy strategies in mycosis fungoides (MF) and Sézary syndrome (SS). Linchuang Zhongliuxue Zazhi. 2019 Feb;8(1):11.

88 Cristofoletti C, Narducci MG, Russo G. Sézary Syndrome, recent biomarkers and new drugs. Linchuang Zhongliuxue Zazhi. 2019 Feb;8(1):2.

89 Alfred A, Taylor PC, Dignan F, El-Ghariani $\mathrm{K}$, Griffin J, Gennery AR, et al. The role of extracorporeal photopheresis in the management of cutaneous T-cell lymphoma, graftversus-host disease and organ transplant rejection: a consensus statement update from the UK Photopheresis Society. Br J Haematol. 2017 Apr;177(2):287-310.

90 Cho A, Jantschitsch C, Knobler R. Extracorporeal photopheresis: an overview. Front Med (Lausanne). 2018 Aug;5:236

91 Trautinger F. Phototherapy of mycosis fungoides. G Ital Dermatol Venereol. 2017 Dec; 152(6):597-606.

92 Berneburg M, Herzinger T, Rampf J, Hoetzenecker W, Guenova E, Meisner C, et al. Efficacy of bath psoralen plus ultraviolet A (PUVA) vs. system PUVA in psoriasis: a prospective, open, randomized, multicentre study. Br J Dermatol. 2013 Sep;169(3):704-8.

93 Geskin L. ECP versus PUVA for the treatment of cutaneous T-cell lymphoma. Skin Therapy Lett. 2007 Jun;12(5):1-4.

94 Querfeld C, Rosen ST, Kuzel TM, Kirby KA, Roenigk HH Jr, Prinz BM, et al. Long-term follow-up of patients with early-stage cutaneous T-cell lymphoma who achieved complete remission with psoralen plus UV-A monotherapy. Arch Dermatol. 2005 Mar;141(3): 305-11.
95 Holtick U, Marshall SR, Wang XN, Hilkens CM, Dickinson AM. Impact of psoralen/ UVA-treatment on survival, activation, and immunostimulatory capacity of monocytederived dendritic cells. Transplantation. 2008 Mar;85(5):757-66.

96 Vieyra-Garcia P, Crouch JD, O’Malley JT, Seger EW, Yang CH, Teague JE, et al. Benign $\mathrm{T}$ cells drive clinical skin inflammation in cutaneous $\mathrm{T}$ cell lymphoma. JCI Insight. 2019 Jan;4(1):124233.

97 Atta M, Papanicolaou N, Tsirigotis P. The role of extracorporeal photopheresis in the treatment of cutaneous T-cell lymphomas. Transfus Apheresis Sci. 2012 Apr;46(2): 195-202.

98 Raphael BA, Shin DB, Suchin KR, Morrissey KA, Vittorio CC, Kim EJ, et al. High clinical response rate of Sezary syndrome to immunomodulatory therapies: prognostic markers of response. Arch Dermatol. 2011 Dec; 147(12):1410-5

99 Edelson RL. Mechanistic insights into extracorporeal photochemotherapy: efficient induction of monocyte-to-dendritic cell maturation. Transfus Apheresis Sci. 2014 Jun; 50(3):322-9.

100 Ventura A, Vassall A, Robinson E, Filler R, Hanlon D, Meeth K, et al. Extracorporeal Photochemotherapy Drives Monocyte-toDendritic Cell Maturation to Induce Anticancer Immunity. Cancer Res. 2018 Jul; 78(14):4045-58.

101 Shinkawa T, Nakamura K, Yamane N, ShojiHosaka E, Kanda Y, Sakurada M, et al. The absence of fucose but not the presence of galactose or bisecting $\mathrm{N}$-acetylglucosamine of human IgG1 complex-type oligosaccharides shows the critical role of enhancing antibody-dependent cellular cytotoxicity. J Biol Chem. 2003 Jan;278(5):3466-73.

102 Suzuki Y, Saito M, Ishii T, Urakawa I, Matsumoto A, Masaki A, et al. Mogamulizumab treatment elicits autoantibodies attacking the skin in patients with adult $\mathrm{T}$ cell leukemia-lymphoma. Clin Cancer Res. 2019 Jul; 25(14):4388-99.

103 Bonnet P, Battistella M, Roelens M, RamWolff C, Herms F, Frumholtz L, et al. Association of autoimmunity and long-term complete remission in patients with Sézary syndrome treated with mogamulizumab. $\mathrm{Br}$ I Dermatol. 2019 Feb;180(2):419-20.

104 Ishida T, Jo T, Takemoto S, Suzushima H, Suehiro Y, Choi I, et al. Follow-up of a randomised phase II study of chemotherapy alone or in combination with mogamulizumab in newly diagnosed aggressive adult T-cell leukaemia-lymphoma: impact on allogeneic haematopoietic stem cell transplantation. Br J Haematol. 2019 Feb;184(3):47983.

105 Fuji S, Shindo T. Friend or foe? Mogamulizumab in allogeneic hematopoietic stem cell transplantation for adult T-cell leukemia/ lymphoma. Stem Cell Investig. 2016 Oct;3: 70.
106 Rubio Gonzalez B, Zain J, Rosen ST, Querfeld C. Tumor microenvironment in mycosis fungoides and Sézary syndrome. Curr Opin Oncol. 2016 Jan;28(1):88-96.

107 Torrealba MP, Manfrere KC, Miyashiro DR, Lima JF, de M Oliveira L, Pereira NZ, et al. Chronic activation profile of circulating CD8+ T cells in Sézary syndrome. Oncotarget. 2017 Dec;9(3):3497-506.

108 Samimi S, Benoit B, Evans K, Wherry EJ, Showe L, Wysocka M, et al. Increased programmed death-1 expression on CD4+ $\mathrm{T}$ cells in cutaneous T-cell lymphoma: implications for immune suppression. Arch Dermatol. 2010 Dec;146(12):1382-8.

109 Cetinözman F, Jansen PM, Vermeer MH, Willemze R. Differential expression of programmed death-1 (PD-1) in Sézary syndrome and mycosis fungoides. Arch Dermatol. 2012 Dec;148(12):1379-85.

110 Wada DA, Wilcox RA, Harrington SM, Kwon ED, Ansell SM, Comfere NI. Programmed death 1 is expressed in cutaneous infiltrates of mycosis fungoides and Sézary syndrome. Am J Hematol. 2011 Mar;86(3): 325-7.

111 Khodadoust M, Rook AH, Porcu P, Foss FM, Moskowitz AJ, Shustov AR, et al. Pembrolizumab for treatment of relapsed/refractory mycosis fungoides and Sezary syndrome: clinical efficacy in a CITN Multicenter phase 2 study. Blood. 2016;128(22):181.

112 Khodadoust MS, Rook A, Porcu P, Foss FM, Moskowitz AJ, Shustov AR, et al. Durable responses with pembrolizumab in relapsed/ refractory mycosis fungoides and Sézary syndrome: final results from a phase $2 \mathrm{mul}-$ ticenter study. Blood. 2018;132 Suppl 1: 2896.

113 Saulite I, Ignatova D, Chang YT, Fassnacht C, Dimitriou F, Varypataki E, et al. Blockade of programmed cell death protein 1 (PD-1) in Sézary syndrome reduces Th2 phenotype of non-tumoral T lymphocytes but may enhance tumor proliferation. OncoImmunology. 2020;9(1):1738797.

114 Wilcox RA, Feldman AL, Wada DA, Yang ZZ, Comfere NI, Dong H, et al. B7-H1 (PDL1, CD274) suppresses host immunity in Tcell lymphoproliferative disorders. Blood. 2009 Sep;114(10):2149-58.

115 Anzengruber F, Ignatova D, Schlaepfer T, Chang YT, French LE, Pascolo S, et al. Divergent LAG-3 versus BTLA, TIGIT, and FCRL3 expression in Sézary syndrome. Leuk Lymphoma. 2019 Aug;60(8):1899-907.

116 Ansell S, Gutierrez ME, Shipp MA, Gladstone D, Moskowitz A, Borello I, et al. A phase 1 study of nivolumab in combination with ipilimumab for relapsed or refractory hematologic malignancies (CheckMate 039). Blood. 2016;128(22):183.

117 Jariwala N, Benoit B, Kossenkov AV, Oetjen LK, Whelan TM, Cornejo CM, et al. TIGIT and Helios Are Highly Expressed on CD4+ T Cells in Sézary Syndrome Patients. J Invest Dermatol. 2017 Jan;137(1):257-60. 
118 Wysocka M, Kossenkov AV, Benoit BM, Troxel AB, Singer E, Schaffer A, et al. CD164 and FCRL3 are highly expressed on CD4+CD26- T cells in Sézary syndrome patients. J Invest Dermatol. 2014 Jan;134(1): 229-36.

119 Spodzieja M, Lach S, Iwaszkiewicz J, Cesson V, Kalejta K, Olive D, et al. Design of short peptides to block BTLA/HVEM interactions for promoting anticancer T-cell responses. PLoS One. 2017 Jun;12(6):e0179201.

120 Johnson LD, Banerjee S, Kruglov O, Viller NN, Horwitz SM, Lesokhin A, et al. Targeting CD47 in Sézary syndrome with SIRPaFc. Blood Adv. 2019 Apr;3(7):1145-53.

121 Folkes AS, Feng M, Zain JM, Abdulla F, Rosen ST, Querfeld C. Targeting CD47 as a cancer therapeutic strategy: the cutaneous T-cell lymphoma experience. Curr Opin Oncol. 2018 Sep;30(5):332-7.

122 Ansell S, Chen RW, Flinn IW, Maris MB, O'Connor OA, Johnson LD, et al. A phase 1 study of TTI-621, a novel immune checkpoint inhibitor targeting CD47, in patients with relapsed or refractory hematologic malignancies. Blood. 2016;128(22):1812.

123 Jiang L, Yuan CM, Hubacheck J, Janik JE, Wilson W, Morris JC, et al. Variable CD52 expression in mature $\mathrm{T}$ cell and $\mathrm{NK}$ cell malignancies: implications for alemtuzumab therapy. Br J Haematol. 2009 Apr;145(2): 173-9.

124 Lundin J, Hagberg H, Repp R, Cavallin-Ståhl E, Fredén S, Juliusson G, et al. Phase 2 study of alemtuzumab (anti-CD52 monoclonal antibody) in patients with advanced mycosis fungoides/Sezary syndrome. Blood. 2003 Jun;101(11):4267-72.

125 Battistella M, Leboeuf C, Ram-Wolff C, Hurabielle C, Bonnafous C, Sicard H, et al. KIR3DL2 expression in cutaneous T-cell lymphomas: expanding the spectrum for KIR3DL2 targeting. Blood. 2017 Dec; 130(26):2900-2.

126 Hurabielle C, Thonnart N, Ram-Wolff C, Sicard H, Bensussan A, Bagot M, et al. Usefulness of KIR3DL2 to Diagnose, Follow-Up, and Manage the Treatment of Patients with Sézary Syndrome. Clin Cancer Res. 2017 Jul; 23(14):3619-27.

127 Marie-Cardine A, Viaud N, Thonnart N, Joly R, Chanteux S, Gauthier L, et al. IPH4102, a humanized KIR3DL2 antibody with potent activity against cutaneous $\mathrm{T}$-cell lymphoma. Cancer Res. 2014 Nov;74(21): 6060-70.

128 Bagot M, Porcu P, Marie-Cardine A, Battistella $\mathrm{M}$, William BM, Vermeer $\mathrm{M}$, et al. IPH4102, a first-in-class anti-KIR3DL2 monoclonal antibody, in patients with relapsed or refractory cutaneous T-cell lymphoma: an international, first-in-human, open-label, phase 1 trial. Lancet Oncol. 2019 Aug;20(8):1160-70.

129 Scarfò I, Frigault MJ, Maus MV. CAR-based approaches to cutaneous T-cell lymphoma. Front Oncol. 2019 Apr;9:259.
130 Spaccarelli N, Rook AH. The Use of Interferons in the Treatment of Cutaneous T-Cell Lymphoma. Dermatol Clin. 2015 Oct;33(4): 731-45.

131 Olsen EA, Rook AH, Zic J, Kim Y, Porcu P, Querfeld C, et al. Sézary syndrome: immunopathogenesis, literature review of therapeutic options, and recommendations for therapy by the United States Cutaneous Lymphoma Consortium (USCLC). J Am Acad Dermatol. 2011 Feb;64(2):352-404.

132 Kaplan EH, Rosen ST, Norris DB, Roenigk HH Jr, Saks SR, Bunn PA Jr. Phase II study of recombinant human interferon gamma for treatment of cutaneous T-cell lymphoma. J Natl Cancer Inst. 1990 Feb;82(3):20812.

133 Dummer R, Hassel JC, Fellenberg F, Eichmüller S, Maier T, Slos P, et al. Adenovirusmediated intralesional interferon-gamma gene transfer induces tumor regressions in cutaneous lymphomas. Blood. 2004 Sep; 104(6):1631-8.

134 Rook AH, Kubin M, Fox FE, Niu Z, Cassin $\mathrm{M}$, Vowels BR, et al. The potential therapeutic role of interleukin-12 in cutaneous T-cell lymphoma. Ann N Y Acad Sci. 1996 Oct; 795:310-8.

135 Vowels BR, Cassin M, Vonderheid EC, Rook AH. Aberrant cytokine production by Sezary syndrome patients: cytokine secretion pattern resembles murine Th2 cells. J Invest Dermatol. 1992 Jul;99(1):90-4.

136 Morrison C, Baer MR, Zandberg DP, Kimball A, Davila E. Effects of Toll-like receptor signals in T-cell neoplasms. Future Oncol. 2011 Feb;7(2):309-20.

137 Terhorst D, Kalali BN, Ollert M, Ring J, Mempel M. The role of toll-like receptors in host defenses and their relevance to dermatologic diseases. Am J Clin Dermatol. 2010; 11(1):1-10

138 Gibson SJ, Lindh JM, Riter TR, Gleason RM, Rogers LM, Fuller AE, et al. Plasmacytoid dendritic cells produce cytokines and mature in response to the TLR7 agonists, imiquimod and resiquimod. Cell Immunol. 2002 Jul-Aug;218(1-2):74-86.

139 Suchin KR, Junkins-Hopkins JM, Rook AH Treatment of stage IA cutaneous T-Cell lymphoma with topical application of the immune response modifier imiquimod. Arch Dermatol. 2002 Sep;138(9):1137-9.

140 Dummer R, Urosevic M, Kempf W, Kazakov D, Burg G. Imiquimod induces complete clearance of a PUVA-resistant plaque in mycosis fungoides. Dermatology. 2003;207(1): 116-8.

141 Chong A, Loo WJ, Banney L, Grant JW, Norris PG. Imiquimod 5\% cream in the treatment of mycosis fungoides-a pilot study. J Dermatolog Treat. 2004 Apr;15(2): 118-9.
142 Deeths MJ, Chapman JT, Dellavalle RP Zeng C, Aeling JL. Treatment of patch and plaque stage mycosis fungoides with imiquimod 5\% cream. J Am Acad Dermatol. 2005 Feb;52(2):275-80.

143 Chiam LY, Chan YC. Solitary plaque mycosis fungoides on the penis responding to topical imiquimod therapy. Br J Dermatol. 2007 Mar;156(3):560-2.

144 Martínez-González MC, Verea-Hernando MM, Yebra-Pimentel MT, Del Pozo J, Mazaira $\mathrm{M}$, Fonseca E. Imiquimod in mycosis fungoides. Eur J Dermatol. 2008 Mar-Apr; 18(2):148-52.

145 Lewis DJ, Byekova YA, Emge DA, Duvic M. Complete resolution of mycosis fungoides tumors with imiquimod $5 \%$ cream: a case series. J Dermatolog Treat. 2017 Sep;28(6): 567-9.

146 Gorden KB, Gorski KS, Gibson SJ, Kedl RM, Kieper WC, Qiu X, et al. Synthetic TLR agonists reveal functional differences between human TLR7 and TLR8. J Immunol. 2005: 174(3):1259-68.

147 Rook AH, Gelfand JM, Wysocka M, Troxel $A B$, Benoit B, Surber C, et al. Topical resiquimod can induce disease regression and enhance T-cell effector functions in cutaneous T-cell lymphoma. Blood. 2015 Sep;126(12): 1452-61.

148 Iwasaki A, Medzhitov R. Toll-like receptor control of the adaptive immune responses. Nat Immunol. 2004 Oct;5(10):987-95.

149 Kim YH, Gratzinger D, Harrison C, Brody JD, Czerwinski DK, Ai WZ, et al. In situ vaccination against mycosis fungoides by intratumoral injection of a TLR9 agonist combined with radiation: a phase $1 / 2$ study. Blood. 2012 Jan;119(2):355-63.

150 Talpur R, Bassett R, Duvic M. Prevalence and treatment of Staphylococcus aureus colonization in patients with mycosis fungoides and Sézary syndrome. Br J Dermatol. 2008 Jul;159(1):105-12.

151 Blümel E, Willerslev-Olsen A, Gluud M, Lindahl LM, Fredholm S, Nastasi C, et al. Staphylococcal alpha-toxin tilts the balance between malignant and non-malignant CD4+ T cells in cutaneous T-cell lymphoma. OncoImmunology.2019 Jul;8(11):e1641387.

152 Tokura Y, Heald PW, Yan SL, Edelson RL. Stimulation of cutaneous T-cell lymphoma cells with superantigenic staphylococcal toxins. J Invest Dermatol. 1992 Jan;98(1):33-7.

153 Fanok MH, Sun A, Fogli LK, Narendran V, Eckstein M, Kannan K, et al. Role of Dysregulated Cytokine Signaling and Bacterial Triggers in the Pathogenesis of Cutaneous T-Cell Lymphoma. J Invest Dermatol. 2018 May;138(5):1116-25.

154 Lindahl LM, Willerslev-Olsen A, Gjerdrum LM, Nielsen PR, Blümel E, Rittig AH, et al Antibiotics inhibit tumor and disease activity in cutaneous T-cell lymphoma. Blood. 2019 Sep;134(13):1072-83.

155 Vermeer MH. Antibiotics can improve CTCL. Blood. 2019 Sep;134(13):1000-1. 